Boosting the Students in Mastering Writing Skill through the Implementation of PPIE (Point, Presentation, Illustration, Explanation) Technique (Zuraini, Misnawati, Asruna Lisa, Eli Nofriati)

\title{
Boosting the Students in Mastering Writing Skill through the Implementation of PPIE (Point, Presentation, Illustration, Explanation) Technique
}

\author{
Zuraini $^{1)}$, Misnawati' ${ }^{2)}$, Asruna Lisa ${ }^{3)}$, Eli Nofriati ${ }^{4)}$ \\ ${ }^{1}$ Almuslim University \\ email: zurainimarwan@gmail.com \\ ${ }^{2}$ Almuslim University \\ email: misnawati1117@gmail.com \\ ${ }^{3}$ Almuslim University \\ email: zurainimarwan@gmail.com \\ ${ }^{4}$ Almuslim University \\ email: nofriatieli38@gmail.com
}

\begin{abstract}
People need to learn writing in English for occupational or academic purposes to write well, students must have good capabilities in the writing process and aspects of writing. The research purposes are: to improve PPIE technique for the students' ability in writing narrative text. And to figure out the students' response to PPIE Technique in writing narrative text. The qualitative and quantitative research methodology was combined by the researcher. In qualitative, the researcher used questionnaires, observation sheets as the instruments of the research to observe and learn. Depending on the quantitative research methodology, the researcher and teacher gave a post-test. The result of the observation sheet for the teachers' performance in cycle 1 had a mean score was about 67.84\%. In cycle 2 shows that the mean score was about $83.14 \%$. The result of the observation sheet for the students' activities in cycle 1 the mean score was 52.54\%. In second cycle mean score was $75.68 \%$. Questionnaires about 12.99 and average score about 3.24. Therefore, the researcher concluded that the PPIE technique could improve the students in writing skill.
\end{abstract}

Key words: Point, Presentation, Illustration, Explanation (PPIE), Writing Skill

\section{Introduction}

Writing is one of the components which support other skill such as listening, reading, and speaking. Writing is an important skill that they need very much in using language. Other students would find many difficulties in writing skill. According to (Wu 2004) says that writing is the series of someone activities to express or convey ideas through written language to make the readers understand.Moreover, (Ariyanti 2016) also states that writing is not easy, because students need to consider processes to produce good writing. Writing is one of the essential skills in English which should be comprehended by students. Writing skill is a language skill that needs significant attention. Writing as one of the language skills is not an innate natural ability. 
Based on the observation that the researcher has to done in SMAN 1 Juli, the researcher found the problems of the students learning, there are first, the students difficult in developing their ideas in writing a good paragraph. Secondly, the students are less motivated in learning writing, and last they are not interested in doing writing activities in the classroom. Another factor of problems by the teacher in teaching writing activities, they are; the teacher was asked the students to write sentences or paragraphs without being given some clues so that is difficult for students to write. The teacher does not understand how to motivate the student in writing. The teacher didn't have interesting learning techniques to improve students writing skill.

Based on the problems above the researcher used the PPIE (Point, Presentation, Illustration, Explanation) technique. Here the researcher only concerns about the use of the PPIE Technique. PPIE Technique is the class grouping where all the students are working in group learning and follows the teacher instructions in take point from writing material, presentation with friends in group learning, give illustration if have problems in developing ideas in writing, and all students in group learning explain and discuss their writing result.

According to (Joffre et al. 2012), PIE is one of the strategies to help students easy to write report, analytical, and argumentative paragraph and increase students' motivation in writing skills. PIE stands for the word Point, Illustration, Explanation. Point, Presentation, Illustration, Explanation (PPIE) Technique is the class grouping where all the students are working in group learning and follows the teacher instructions in take point from writing material, presentation with friends in group learning, give illustration if have problems in developing ideas in writing, and all students in group learning explain and discuss their writing result. Point, Presentation, Illustration, Explanation (PPIE) can improve the student's motivation in developing their ideas in writing a aragraph and help the students understand the role in writing a paragraph.

There are four main steps in PPIE Technique they are; First, "Point" in this step the student takes the main point from writing material topic before the topic developed into a paragraph. Second "Presentation" in this step the students will presentation their writing topic with group learning and also develop the main point after knowing before. Third "Illustration" in this step, the teacher can give and show the illustration if the students have problems in developing ideas in writing a paragraph. fourth "Explanation" is the students in group learning give more explanation about their writing result and also discussed it in front of the class. 
Boosting the Students in Mastering Writing Skill through the Implementation of PPIE (Point, Presentation, Illustration, Explanation) Technique (Zuraini, Misnawati, Asruna Lisa, Eli Nofriati)

\section{Review of Related Literature}

The steps to implement Point, Presentation, Illustration, Explanation (PPIE) Technique in teaching writing in the classroom are as follow:

1. The teacher prepares the writing material for students

2. The teacher explains the topic and meaning of writing material to students.

3. The teacher instructs students to determine and following the step of Point, Presentation, Illustration, Explanation (PPIE) Technique

4. Then the teacher asks the students to identify main point or specific information from the topic before the topic to develop into a paragraph

5. After the students identify the main point, then the teacher asks the students to present their writing topic with their group learning and also develop the main point before into a group paragraph. The teacher talks to the students to be as creative as possible.

6. Then, the teacher explains the format of writing that the students would write. In this case, the teacher can give and show the illustration if the students have problems developing ideas in writing a paragraph

7. The teacher asks the students to give more explanation about their writing result by finding some important information from the topic. In this case, the teacher leads the students to have ideas to be written a text

8. The teacher asks each of the students to read their writing result aloud to the class and encourages the rest of the class to take notes about historical points they learn from other students' writings

9. The teacher evaluates the students writing activity

10. Finally, the teacher closes the teaching and learning process.

\section{Method of Research}

The research methodology of this research is used Classroom Action Research (CAR). There are two kinds of classroom action research, and the researcher would be done through Collaborative Classroom Action Research (CCAR). According to (Barone and Eisner 2012), "The fundamental aim of action research is to improve practice rather than knowledge". In 
addition, (Delphie 2014) says that classroom action research is a form of systematic and reflective research conducted by educators or teachers by giving certain action to improve the quality of teaching practices in the classrooms so that those practices become more professional.

In this research, the researcher used a procedure of collaborative action research. The procedures of the Collaborative Classroom Action Research (CCAR) are referred to (Kemmis, McTaggart, and Nixon 2014) that consist of five steps namely: Preliminary Study, Planning the action, Implementing the action, Observing the action, and Reflecting on the action.

\section{Figure 3.1 The Classroom Action Research Procedures}

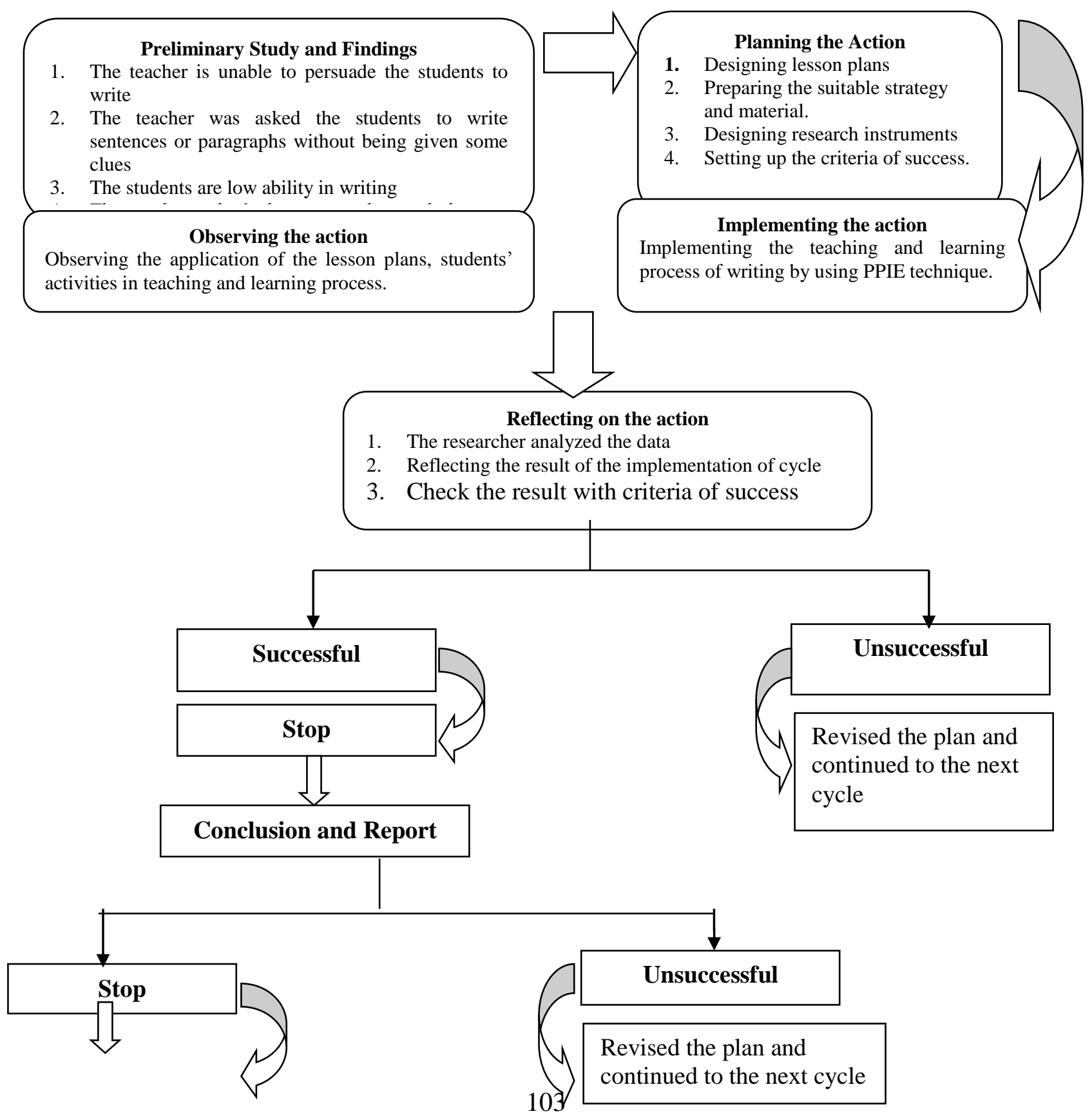


Boosting the Students in Mastering Writing Skill through the Implementation of PPIE (Point, Presentation, Illustration, Explanation) Technique (Zuraini, Misnawati, Asruna Lisa, Eli Nofriati)

\section{Conclusion and}

Report

\section{Results and Discussion}

\section{(Adapted from Kemmis and Mctaggart Model 2014)}

To know the action is successful or not, the researchers as the teacher and the collaborator who observe the teaching and learning process in the classroom made a reflection. The reflection can be seen based on criteria of success and was designed to know whether the research of cycle 1 was a success or not. The analysis in detail is discussed below.

\section{4,1. Analysis of the Researcher's Performance during Teaching of Writing Based on the Observation Sheet in Cycle 1}

The analysis of researchers performances was done based on the result of the researcher's activity in teaching writing in the classroom. The researcher analyzed the writing activity based on the observation sheet that had been set before. The observation sheet was filled by the researcher about the researcher's performance in the teaching process. The result can be explained as follow:

In the first meeting, the researcher used 15 minutes of the session to prepared the class for the English subject. These 15 minutes were also used to greeting and check the student's attendance list. Then, the researcher asked some questions about the previous lesson and the condition of students to brainstorm the student's motivation in learning writing. The researcher used narrative text about the topic of "Malin Kundang". Then, the researcher explained to students the writing activity that helped them to identify the elements of a text. In the end session of the first meeting, the researcher gave some questions to students about the Narrative text. After the students finished answering the questions, the teacher takes the conclusion about the material and closed the learning process.

In the second meeting, the researcher reviewed the writing material about the narrative text that included social function, generic structure of the narrative text, and the researcher also explained how the role of PPIE technique, and the students paid good attention to the researcher explained. After that teacher divided the students into some groups, each group consisting of three or four students. Before the teacher gave some topics of narrative text to the students, the teacher observes the activities students in the class to choose as the leader of group learning. And then the teacher gave the topic about "Sangkuriang". During the teaching and learning process, 
the teacher controls the student's activity and facilitates the students if they need some suggestions about how to make a good paragraph. After wrote a narrative text, the teacher asked the leader of students to read the result of the narrative text in front of the class.

In the third meeting, the researcher gave a post-test for students. The activities could run well and there was no significant problem in the classroom. The post-test in cycle 1 was done to find the mean score of the students' writing designed by using the PPIE technique. Based on the result of the observation sheet for the researcher in the first cycle of the third meeting showed that the total score about 65 and the mean score was $67.84 \%$. The researcher also had good performance in teaching writing by using PPIE Technique and the teaching-learning process could run well based on the lesson plans.

\subsection{Analysis of the Students Writing Activities Based on the Observation Sheet in Cycle 1}

The analysis of students writing activities was done based on the result of the students' activity in writing during the learning process in the classroom. The researcher analyzed the students' writing scores based on the criteria that had been set before. The observation sheet was filled by the researcher to know the student's activities in the teaching and learning process. From the analysis, it was found that some students are not interested and motivated in writing subject. The problems were dealt with about how to write well and develop their ideas into a good paragraph, they also felt confident and the most important write well with the good content, organization, discourse, syntax, vocabulary, and mechanics.

Based on the observation sheet of students writing activities, the researcher found that some students had difficulties to respond the teacher's explanation about the narrative text. Then, the students had difficulty in developing their ideas in writing something, especially in writing narrative text. Furthermore, the students had difficulty writing a good paragraph with grammar accurately, unity, coherence, and completeness. The students also had low motivation in learning writing so that they are poor in writing skills.

Based on the result of the observation sheet for the students in cycle 1 showed that the mean score was $52.54 \%$. It meant that the students' writing skills needed to improve by the teacher.

\subsection{Analysis the Students Test Result in Learning Writing of Cycle 1}


Boosting the Students in Mastering Writing Skill through the Implementation of PPIE (Point, Presentation, Illustration, Explanation) Technique (Zuraini, Misnawati, Asruna Lisa, Eli Nofriati)

Analysis of the Students Test Result in Learning Writing of Cycle 1 by using PPIE technique in the first cycle was done to answer the problems of research question about how does PPIE Technique improve the students writing skill of SMAN 1 Juli in Narrative text. The finding showed that the students mean score in the post-test of the students writing skill in the cycle 1 was 64.68, which meant that the students' score in writing skill did not meet the criteria of success and it shows that using the PPIE technique did not improve students' writing skill yet.

The post-test in the first cycle was done to find the mean score of the student's ability in writing a narrative text about legend after the class was treated by the action of implementation by using PPIE technique to improve students' writing ability in writing, the researcher used the formula below:

Thus, $\bar{x}=\frac{\sum f x}{N}=\frac{1035}{16}=64.68$

Based on the post-test activity in the first cycle, the researcher got the result was the score of post-tests of the students does not meet the criteria of success. The total score was 1035. From the analysis above, the mean score of the students in writing was 64.68 and it was categorized in the level "good". The students are also actively involved in learning writing by using the PPIE technique.

To improve the students' writing skill more significantly, the researcher and the collaborator teacher has conducted the second cycle. The reason of conducted the second cycle was on the criteria of success was not achieved, and the result on the student's post-test in the first cycle did not meet the criteria of success. The application of the second cycle needed some revision, such as the teacher teaching style, and the topic material in the teaching-learning process.

The reflection in the second cycle is similar to the first cycle. It was still centered on the result of the teaching and learning process, and the students learning results after the improvement given this cycle. The data analysis was focused on the students' performance and the students' ability in writing skill. The result of the analysis was elaborated as follow:

\subsection{Analysis of the Researcher's Performance During Teaching of Writing Based on the} Observation Sheet in Cycle 2 
Based on the observation sheet for the researcher in implementing of Point, Presentation, Illustration, Explanation (PPIE) Technique, in teaching writing skill, some facts were identifying. It can be explained as follow:

In the first meeting, the researchers prepared the topic material about "Malin Kundang". Then the teacher gave the text of Malin Kundang to students and then the teacher asked the students to read the text. Then, the teacher divided the students into some groups. After that, the teacher explains how to develop ideas into a good paragraph. Then the teacher asked the students to makes the frameworks about the topic based on the generic structure of a narrative text. After that, the teacher asked the students to develop their ideas into a good narrative text based on the frameworks before. During the teaching and learning process, the teacher controls the student's activity and facilitates the students in groups, and gave the illustration if they need some suggestions about how to make a good paragraph.

In the second meeting, the teacher shares the materials of narrative text. Then, the teacher gave a few minutes for the students to read the teaching materials and examples of narrative text that is "Malin Kundang". After that the teacher took the teaching materials of narrative text that had been given for students, then the teacher asked the students to imagine the content of the narrative text as creative. Then, the students explained and described narrative text by using their own words that had been imaged before, and then the teacher explained again about the format of writing that the students would write and about the PPIE technique. In this meeting, the researcher could motivate the students in teaching writing by using PPIE technique in the classroom.

In the third meeting, the researcher gave a post-test for students. The activities could run well there was no significant problem in the classroom. The post-test in cycle 2 was done to find the mean score of students' abilities in writing skill by using PPIE technique. Based on the result of the observation sheet for the researcher in the second cycle showed that the mean score was 83.14\%. In the last activity of the third meeting, the researcher gave the questionnaires to students.

\subsection{Analysis of the Students Writing Activities Based on the Observation Sheet in Cycle 2}

As in the first cycle, the analysis of learning results was still done based on the result of the students' performance in writing skills during their activities in writing the narrative text. The 
Boosting the Students in Mastering Writing Skill through the Implementation of PPIE (Point, Presentation, Illustration, Explanation) Technique (Zuraini, Misnawati, Asruna Lisa, Eli Nofriati)

researcher helped by the collaborator teachers used the indicators that have been set before to analyze the students learning results. Based on the observation sheet for the students in applying the PPIE technique in the teaching of writing skill, some facts were identifying. In general, the result showed in the second cycle had met the criteria.

Based on the result of the observation checklist, it was identified that after being treated with the improved technique. The teaching and learning process became much better and brought a good impact to the improvement of the learning result of the students. In terms of the students' participation in the learning process, it turned out the activities applied in the second cycle have worked well in motivating the students to work well in writing. In cycle 2, the students had shown significant improvement especially in the student's motivation in learning writing by using the PPIE technique.

In the third meeting of second cycle, the researcher found that the result of the observation sheet for students was about 69 , and the mean score was $75.68 \%$. It showed that the scores in the second cycle of the class better than the score in the first cycle. So, it meant that the students writing skills on the narrative text had been improved or was met the criteria of success.

\subsection{An Analysis the Students Test Result in Learning Writing of Cycle 2}

Analysis of the students test result through the PPIE technique in the second cycle was done to answer the problems of the research question about how does PPIE Technique improve the students writing skill of SMAN 1 Juli in Narrative text. The finding showed that the students' mean score in the post-test of the students writing skill in the second cycle was 83.75. It meant that the students' score in writing skill was met the criteria of success and it shows that the PPIE technique can improve the students writing skill especially in writing a narrative text about the legend.

The post-test in the second cycle was also held to find the mean score of the students' ability in writing skill by using PPIE technique through narrative text about a legend. To find out the mean score of student's ability in writing skill, the researcher used the formula below:

Thus, $\bar{x}=\frac{\sum f x}{N}=\frac{1340}{16}=83.75$

From the analysis above, the average achievement of the student's post-test was 83.75 and categorized in the level "Excellent". It can be concluded that the student's achievement in writing skill by using PPIE technique had a significant improvement. 
Jurnal CULTURE (Culture, Language, and Literature Review), 8(1), Mei 2021, 100-111

Copyright (C) 2021, Jurnal CULTURE (Culture, Language, and Literature Review), e-ISSN 2775-4618, p-ISSN 2355-8660

\subsection{Analysis of the Students Respond Toward the Implementation of PPIE Technique Based on Questionnaires in Cycle 2}

Analysis of the students' responses based on questionnaires was done to know about how the students respond toward the implementation of the PPIE Technique in learning writing of the narrative text. Based on the result of questionnaires which were distributed to students after cycle 1 was fully accomplished. It was found that the students felt happy and were not burdened when they were assigned in writing narrative text, and also the students enjoy or fun with the PPIE technique as a new technique in teaching writing skill in the classroom. The researcher was found that the mean score for each variable of several items toward the students' responses about the lesson could be interpreted on the table below:

Table 4.5 The Result of the Students Respond on Questionnaires

\begin{tabular}{|c|l|c|c|c|}
\hline No & \multicolumn{1}{|c|}{ Variable Measured } & $\begin{array}{c}\text { Questionaires } \\
\text { Number }\end{array}$ & $\begin{array}{c}\text { Total } \\
\text { Score }\end{array}$ & Mean Score \\
\hline 1 & $\begin{array}{l}\text { Students show great motivation in } \\
\text { writing activity }\end{array}$ & $2,13,14$ & 11.0 & 3.66 \\
\hline 2 & $\begin{array}{l}\text { Easy to comprehend the writing } \\
\text { material }\end{array}$ & 3,5 & 7.0 & 3.5 \\
\hline 3 & Interest to the activity & $1,4,8,9,10,15$ & 16.6 & 2.76 \\
\hline 4 & Respected and brave to give opinion & $6,7,11,12$ & 12.3 & 3.07 \\
\hline & Total Score & & $\mathbf{4 6 . 9}$ & $\mathbf{1 2 . 9 9}$ \\
\hline & Average Score & $\mathbf{1 1 . 7 2}$ & $\mathbf{3 . 2 4}$ \\
\hline
\end{tabular}

Based on Table 4.5, it was found that the mean score for each variable from several items towards the maximum score (by using the Likert scale) can be interpreted as follows:

1. Students show great motivation in writing activity with the mean score of about 3.66 and criteria: Strongly Agree.

2. Easy to comprehend the writing material with the mean score of about 3.5 and criteria: Strongly Agree.

3. Interest in the activity with a mean score of about 2.76 and criteria: Agree. 
Boosting the Students in Mastering Writing Skill through the Implementation of PPIE (Point, Presentation, Illustration, Explanation) Technique (Zuraini, Misnawati, Asruna Lisa, Eli Nofriati)

4. Respected and brave to give an opinion with the mean score of about 3.07 and criteria: Strongly Agree.

5. Total score on questionnaires about 12.99 and average score about 3.24 in criteria Strongly Agree.

Based on the finding of this research, in the first cycle, it was evident to require improving the students' ability in writing skill by using PPIE technique. As the result, the students were actively involved in the teaching and learning process by commenting, responding, and questioning. The students were highly motivated by showing their good motivation and attitude. They looked interested because the class atmosphere was not boring instead of exciting. Furthermore, the PPIE technique was interested and help the students to relax in learning writing and easy for them to develop their ideas in writing a paragraph.

The result of the observation sheet for the students' activities in cycle 1, the mean score was about $52.54 \%$. In the second cycle, the mean score was $75.68 \%$. It showed that the scores in the second cycle of the class better than the score in the first cycle. So, it meant that the students writing skill on the narrative text had been improved or was met the criteria of success by using PPIE technique.

The students' score of post-test in the first cycle was 64.68. In the second cycle, the result was not so different from the first cycle's result. The result of the posttest in the second cycle was 83.75. Moreover, the students showed their interest and eagerness in learning writing and help them to improve their ability in writing skill than in the first cycle. It could be seen from the average score of post-tests in the second cycle was 83.75 and it was bigger than the average of post-test in the first cycle. It means that the result of the second cycle has met the predetermined criteria of success.

Based on the result of the questionnaire which was distributed to the students after the second cycle was fully accomplished. It was found that the students felt happy and were not burdened when they were assigned to practice and wrote the narrative text, and also the students enjoy and fun with the PPIE technique in teaching writing in the classroom. The questionnaire was in the Indonesian language so that the students easy to understand the declaration of the questionnaire.

Therefore, based on the data found from the first cycle and second cycle of this research, it was proved that teaching writing by using the Point, Presentation, Illustration, Explanations 
Jurnal CULTURE (Culture, Language, and Literature Review), 8(1), Mei 2021, 100-111

Copyright (C) 2021, Jurnal CULTURE (Culture, Language, and Literature Review), e-ISSN 2775-4618, p-ISSN 2355-8660

(PPIE) Technique could motivate the students and improving the student's ability in writing skill. Students also could write the narrative text, felt relax and enjoy the teaching and learning process by using the PPIE technique through narrative text.

\section{Conclusion}

The implementation of the Point, Presentation, Illustration, explanation (PPIE) technique in teaching writing through narrative text was conducted in two cycles that consisted of three meetings of each cycle. After analyzing the data that had been collected the researcher found that, the mean score of post-test in the first cycle was 64.68 and it is classified into the "good" category. In the second cycle, the researcher found that the mean score of the post-test was 83.75 and it is classified into the "excellent" category. The researcher concluded that the students' average score in writing of the second cycle was higher than that in the first cycle.

\section{References}

Ariyanti, Ariyanti. 2016. "Shaping Students' Writing Skills: The Study of Fundamental Aspects in Mastering Academic Writing." Indonesian Journal of EFL and Linguistics. doi: 10.21462/ijefll.v1i1.5.

Barone, Tom, and Elliot W. Eisner. 2012. Arts Based Research.

Delphie, Bandi. 2014. Penelitian Tindakan Kelas (Classroom Action Research).

Joffre, Olivier P., Elodie Segura, Ariel Savina, and Sebastian Amigorena. 2012. "CrossPresentation by Dendritic Cells." Nature Reviews Immunology.

Kemmis, Stephen, Robin McTaggart, and Rhonda Nixon. 2014. The Action Research Planner.

Wu, Hsing-Ling Carol. 2004. 'Language -Switching in Chinese ESL Students' Writing Processes." 